than half his life in the single-hearted pursuit of science and of kindly service to his fellow-men.

C. D.

\title{
CORRESPONDENCE.
}

THE VOLCANIC GEOLOGY OF EAST FIFE.

Sir,-Mr. Balsillie is to be congratulated on his resolute tackling of the Carboniferous igneous rocks of Fifeshire. It may be permissible, however, at the same time, to express regret that in his latest paper ${ }^{1}$ he has countenanced the idea of the Lower Carboniferous age of the East Fife vents on the basis of evidence obtained from one of the least typical of them.

Everyone must agree that the evidence Mr. Balsillie has marshalled is overwhelmingly in favour of the Lower Carboniferous age of the Largo Law vent. It is one of the largest of the Fife vents, very different in size from the small "greenhill" type of vent which appears to be characteristic of late-Carboniferous and Permian vulcanicity. It appears to resemble the great vent of the Heads of Ayr, ${ }^{2}$ which is also demonstrably of Lower Carboniferous age, but which, unlike Largo Law, has not proceeded to eruption of lava. It is full of fragments of the subjacent Old Red Sandstone andesites, and not a single fragment of Lower Carboniferous lava has been found in spite of repeated search. Hence the small basic alkaline intrusions by which it is pierced are probably of much later age. There can hardly be any doubt but that the Heads of Ayr volcanic channel has been utilized by the recrudescent late-Carboniferous igneous activity. I would suggest that the similar intrusions in Largo Law are also possibly of later date than the main filling of the vent; and in this connexion it would be interesting to have a petrographical comparison of the unquestionably intercalated ash, agglomerate, and lava, with the material filling the volcanic orifice or orifices. Later agglomerate fillings may perhaps be distinguishable from earlier (e.g. the large blocks of earlier ash in the western vent of the Largo shore, Mr. Balsillie's paper, p. 541).

The argument for the late-Carboniferous or Permian age of many of the Fifeshire vents does not rest entirely on petrographical evidence; and the fact that analcite- and nepheline-bearing rocks occur in earlier stages of the Carboniferous igneous period has little bearing on the problem. Such rocks in similar age relations are found also in the Bathgate Hills and in the west, but clearly do not militate against the Permian age of the western vents of the Fife type. Many of the analcite-basalts and monchiquites, as well as teschenites, of East Lothian are stated in the East Lothian

1 Geol. Mag., Vol. LX, 1923, pp. 530-42.

2 Trans. Geol. Soc. Glasgow, vol. xvi, 1917-18, pt. iii, pp. 340-3. 
Memoir to be intrusive into rocks of the upper part of the Carboniferous Limestone Series. It is therefore difficult to believe that these rocks (which are identical with the vent intrusions of Fifeshire and Ayrshire) can be connected with Lower Carboniferous vulcanicity.

The argument from analogy has been used in comparing the ages of the Fifeshire and Ayrshire vents. The numbers, sizes, and contents almost exactly correspond in the two cases; but whereas the Ayrshire vents cut late-Carboniferous rocks, only one of the Fife examples cuts the Millstone Grit, and one doubtful case the Coal Measures. Admittedly the argument from analogy must be used with extreme caution, but it is fairly strong in this case. If the Ayrshire region had been eroded, say, 1,000 feet deeper, most of the Upper Carboniferous would have been cleared a way, the geological relations of the vents would have been very similar to those in Fife, and the same arguments as those used by Mr. Balsillie might have been advanced to prove their Lower Carboniferous age.

\section{Geological Department,}

G. W. TYRRFLL.

UNIVERSITY OF GLASGOW.

17th Dicember, 1923.

\section{DIATOMACEOUS EARTH IN EGYPT.}

SIR,- When examining oil-well samples from a recently drilled test-bore undertaken by the Egyptian Government at Abu Shaar on the western shores of the Red Sea, I was struck by the presence of small round objects just discernible by the aid of a pocket lens, in beds of siliceous laminated shales.

Having prepared a slide of the material for examination under the microscope, I submitted it to Dr. W. F. Hume, Director of the Geological Survey of Egypt, who recognized the presence of the diatom Coscinodiscus, this being the first time fossil diatoms have been noted in Egypt.

These shales, or diatomaceous earths, occur interbedded in the gypsum-salt series which we regard as belonging to the upper part of the Miocene succession-a series which is strongly developed in the oilfields region of this country, and which has been looked upon for some time past as representing lagoon conditions.

Colonel H. G. Lyons was informed of the discovery, and at his suggestion a sample of this material was sent to Dr. Rendle, of the British Museum, Natural History Department, and was subsequently submitted to Sir Nicolas Yermoloff, who identified fortyfive different species belonging to the following ten genera :-

$\begin{array}{ll}\text { Coscinodiscus. } & \text { Biddulphia. } \\ \text { Actinocyclus. } & \text { Eupodiscus. } \\ \text { Actinoptychus. } & \text { Rhabdonema. } \\ \text { Chotoceros. } & \text { Surirella. } \\ \text { Rhizosolenia. } & \text { Navicula. }\end{array}$

